\title{
THE USE OF WRITTEN CORRECTIVE FEEDBACK TO IMPROVE THE TENTH GRADE STUDENTS' WRITING SKILL OF DESCRIPTIVE TEXT
}

\author{
M. Ubayu Yahya \\ ubayuy@gmail.com \\ Suhartono \\ nurmantono@yahoo.com
}

\begin{abstract}
Writing is a difficult process of how to share or state some ideas or opinions onto paper. Through text, students' knowledge could be revealed. The wrong usage or application could be considered as the indicator that learning is taking place; however this kind of condition shouldn't be allowed to happen continuously. The teacher should acknowledge where the students make the most error to give the appropriate technique. The research problems of this research are (1) What are written corrective feedbacks used by the tenth grade teacher in writing of descriptive text? (2) How do the students response to the written corrective feedbacks which are used by the tenth grade teacher in writing of descriptive text?

In this research, the writer used a descriptive case study to attain the data. The subjects of this research are the English teacher and the tenth grade students at SMK PGRI 1 KEDIRI. The research is done in two days. The writer uses instruments such as interview, field note, questionnaire and students' written text.

The finding of this research is that (1) the teacher uses direct, indirect and metalinguistic corrective feedback; (2) direct corrective feedback gets $48 \%$ definitely like and 38\% like, indirect corrective feedback gets $2 \%$ definitely like, $8 \%$ like and $2 \%$ do not like, and metalinguistic corrective feedback gets $2 \%$ like.

Based on the findings, it can be concluded that: (1) the teacher used direct corrective feedback to correct almost all the students' errors on their written text of descriptive text; (2) students preferred direct corrective feedback more than the others. The writer suggested that the teacher should acknowledge the theories of written corrective feedback so the students do not understand direct corrective feedback only but all types of written corrective feedback.
\end{abstract}

Key Words: Writing, Direct Corrective Feedback, Indirect Corrective Feedback, Metalinguistic Corrective Feedback. 


\section{BACKGROUND}

English is a language that is used by almost everyone in the world. In Indonesia, English is a foreign language and it is as a compulsory subject that is learned in schools. Learning English means learning the way to communicate by that language as a target language, either in speaking or writing expressions. Some Senior High Schools implement the 2006 Curriculum focusing on developing the students' skill in using the English language as a communication tool. In this curriculum, the text book uses genre. Johns (2002: 6) stated that genre refers to named, socially constructed discourse, and text type to organizational patterns within more complex discourses. Knapp and Watkins (2005: 22) also state "Genre (as a textual category) is theorized as an abstraction or classification of real-life, everyday texts (registers). By investigating genres, the students can perceive the differences in structure, form and apply what they learn to their own writing.

Writing is one of the four language skills, which is taught in the school. Larsen and Anderson (2013) explain "Writing is an important skill, to be developed from the beginning of language instruction". Many students have great difficulty writing. Putting words on paper (or a screen) often seems to mystify young writers. They struggle with a range of questions, both broad and specific, from "What is an essay?" and "Where do I get ideas?" to "What is a topic sentence?" and when they've finished, "How do I know if I've been convincing?". Brown (2000: 337) explains "Writing is a way to end up thinking something you couldn't have started out thinking". Writing is, in fact, a transaction with words whereby you free yourself from what you presently think, feel, and perceive". It means that writing is a process of thinking and expressing their feelings, idea, thoughts and their opinions".

Almost all the students in every level of education whether they are the senior one or even the university students will find that writing is not an easy process. Knapp and Watkins (2005: 14) state "Learning to write is a difficult and complex series of processes that require a range of explicit teaching methodologies throughout all the stages of learning". English is different from Indonesia in its structure, phonology, and lexical meaning. So learning English is different from learning Indonesian. That is why, the students who learn English may produce many errors. Errors usually occur in the productive skills, speaking and writing, but to analyze errors in productive skills in short time is not easy. It takes time, money, and requires a high ability of an analysis. 
| Volume: 1 | Number: 2 | October 2016 | ISSN: 2503 - 4405|

There are many strategies that can be used to improve the writing skill of the students. One of them is written corrective feedback. Bitchener and Knoch (2008: 409) argue "Written corrective feedback (WCF) is to help students acquire and demonstrate mastery in the use of targeted linguistic forms and structures". Russell and Spada (2006: 134) also state "Corrective feedback refers to any feedback provided to a learner, from any sources, that contains evidence of learner error of language form". It means that feedback in language teaching takes the form of positive reinforcement or correction for the students.

The explanations above are supported by Karimi in his research (2016). He investigates the effect of different types of teacher written corrective feedback (WCF) on Iranian EFL learners' writing accuracy focusing on two functions of English articles (the first mention and anaphoric reference) and simple past tense (regular and irregular). Ninety-four Iranian learners of English were assigned to three experimental groups of direct feedback group $(n=24)$, indirect feedback group $(n=24)$, direct+indirect feedback group $(n=24)$, and one control group $(n=22)$. The results revealed a statistically significant difference in the performance of the three groups.

Moreover, a research by Mahmoodi and Rajabi (2015). They investigate which type of feedback (oral or written) is more effective in enhancing learner's grammatical knowledge. In order to answer questions, 43 students studying English in one of language schools in Kermanshah, Iran at intermediate level participated in the study. The feedback provided was in the form of oral mode in Group 1 and written mode in Group 2. The results showed that the students in both groups demonstrated improvement in both G1 and G2 though the oral one performed better compared to the written mode. However, in terms of their attitude no special form of changing in their attitude was observed. Also no selfregulation was observed on the part of learners.

Based on the explanation above, the first research investigated the effect of different types of teacher written corrective feedback which is focused on English article and simple past. The second research investigated oral or written feedback is more effective in enhancing learner's grammatical knowledge. The writer is interested in analyzing what written corrective feedback which implemented by the English teacher to improve the tenth grade students' writing skill of descriptive text and the students' response to the teacher's written corrective feedbacks. Therefore, the title of this research 
| Volume: 1 | Number: 2 | October 2016 | ISSN: 2503 - 4405|

is "The Use of Written Corrective Feedback to Improve the Tenth Grade Students' Writing Skill of Descriptive Text at SMK PGRI 1 KEDIRI in the Academic Year 2015/2016".

\section{METHOD}

In this research the writer used qualitative research and type of this research is descriptive case study. Qualitative research is characterized by its aims, which relate to understanding some aspect of social life, and its methods which (in general) generate words, rather than numbers, as data for analysis (Patton and Cochran, 2002: 2). Meanwhile, Marczyck et al (2005: 17) add "Qualitative research involves studies that do not attempt to quantify their results though statistical summary or analysis". Qualitative studies typically involve interview and observations without formal measurement." From the statements above it means that in this qualitative research the writer describes the result and does not use statistical summary or analysis to find the finding.

Moreover, to attain the data, the writer used a descriptive case study. Ary et al. (2010: 454) argue "A qualitative case study is one type of qualitative research method which provides in-depth, reach, and holistic description." According to Dornyei (2007: 24), qualitative research involves data collection procedures that result primarily in openended, non-numerical data which is then analyzed primarily by non-statistical methods. Typical example: interview research, with the transcribed recordings analyzed by qualitative content analysis".It means that the data and the method of qualitative research does not use numerical data but in the form of words to be sentences that is called description.

The writer analyzed the data which was the most complex and mysterious phase of qualitative research (Ary et al, 2010: 481). The statement above means that analyzing the data is the most important phase because it will establish the result of the research. Analysis involves reducing and organizing the data, synthesizing, searching for significant patterns, and discovering what is important (Ary et al, 2010: 481). It means that the writer must organize the data and try to make sense of it in order to find what is important from the data. This analysis has three stages they are; organizing and familiarizing, coding and reducing, and interpreting and representing.

In this research the writer examined the data and analyzed it, then described the result so that the writer got a conclusion about written corrective feedbacks which used by 
| Volume: 1 | Number: 2 | October 2016 | ISSN: 2503 - 4405|

the tenth grade teacher and the students' response to the teacher's written corrective feedbacks at SMK PGRI 1 KEDIRI.

\section{RESULT AND CONCLUSION}

\section{A. Result}

This research is focused on what kind of written corrective feedbacks which used by tenth grade teacher and students' response to the teacher's written corrective feedbacks in writing of descriptive text. The writer did the research in two days. First day, the writer observed the classroom. He found how the teacher gave the written corrective feedback to the students' written text. Second day, the writer distributed the students' written text with the teacher's feedback and questionnaire based on the teacher's written feedback. After finishing the questionnaire, the writer did an interview with the teacher and four students who had the highest until the lowest score on their written text.

To find what written corrective feedback used by the tenth grade teacher, the writer used types of written corrective feedback by Ellis (2009: 98). There are seven types of written corrective feedback; the writer gave code as follows:

Table 1

Code of Written Corrective Feedback

\begin{tabular}{|c|l|l|}
\hline No & \multicolumn{1}{|c|}{$\begin{array}{c}\text { Kind of Written Corrective } \\
\text { Feedback }\end{array}$} & \multicolumn{1}{c|}{ Code } \\
\hline 1 & Direct Corrective Feedback & DCF \\
\hline 2 & Indirect Corrective Feedback & ICF \\
\hline 3 & Metalinguistic Corrective Feedback & MCF \\
\hline 4 & Focused Feedback & FF \\
\hline 5 & Unfocused Feedback & UFF \\
\hline 6 & Electronic Feedback & EF \\
\hline 7 & Reformulation Feedback & RF \\
\hline
\end{tabular}

From the students' written text which had been corrected by the teacher, the writer read and analyzed it by giving code to all the students' errors based on the teacher's written corrective feedback. He analyzed every student's error and put the codes near it. Then the writer created a questionnaire to find the students' response based on their error and written corrective feedback from the teacher. 
For example: Indicate your reaction to each of the following comments by circling 1, 2, 3, or 4 .

1 - means 'definitely like'

2 - means 'like'

3 - means 'do not like'

4 - means 'definitely do not like'

1. (Teacher crosses out 'he' and replaces with 'she')

By giving questionnaire, the writer found the students' response to the teacher's written corrective feedback. After finding the teacher's written corrective feedbacks and the students' response, he created a table to report the research finding. The table is the recapitulation of the students' error classified based on the written corrective feedbacks which made by the teacher and students' response based on the questionnaire.

Table 2

Recapitulation of the Result of Students' Written Text

\begin{tabular}{|c|c|c|c|c|c|c|c|c|c|}
\hline \multirow{3}{*}{$\mathbf{X}$} & \multicolumn{8}{|c|}{$\begin{array}{l}\text { WRITTEN CORECTIVE } \\
\text { FEEDBACK }\end{array}$} & \multirow{3}{*}{ w } \\
\hline & \multicolumn{2}{|c|}{ DCF } & & \multicolumn{2}{|c|}{ ICF } & \multicolumn{3}{|c|}{ MCF } & \\
\hline & $\overrightarrow{0}$ & $\rightarrow$ & d园 & - & $\theta$ & 可 & 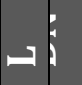 & a & \\
\hline$x-1$ & & 2 & & & & & & & 2 \\
\hline$凶 \sim$ & 3 & 1 & & & & & & & 4 \\
\hline$x m$ & 2 & 4 & 1 & & & & & & 7 \\
\hline 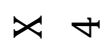 & 1 & 2 & & & & & & & 3 \\
\hline$x$ in & 3 & 1 & & & & & & & 4 \\
\hline$\times 0$ & 3 & & & 2 & & & & & 5 \\
\hline$凶 \wedge$ & 6 & & & 1 & & & & & 7 \\
\hline$\rtimes \infty$ & 2 & 5 & & & 1 & & & & 8 \\
\hline
\end{tabular}

M. Ubayu Yahya \& Suhartono | 51 The Use of Written Corrective Feedback to Improve the Tenth Grade Students' Writing Skill of 


\begin{tabular}{|c|c|c|c|c|c|c|}
\hline$\times \sigma$ & 3 & & & 1 & & 4 \\
\hline$\ddot{x} 0$ & 1 & 3 & & 1 & & 5 \\
\hline$\ddot{x}-$ & 1 & 3 & & & & 4 \\
\hline$\ddot{x} \sim$ & & 2 & & & & 2 \\
\hline$\ddot{x} m$ & 1 & & & & & 1 \\
\hline$\ddot{x}+$ & 2 & 2 & & 1 & 1 & 6 \\
\hline$\ddot{x}\llcorner$ & 2 & & & 1 & & 3 \\
\hline$\ddot{x} 0$ & 1 & 1 & & & 1 & 3 \\
\hline$\vec{x} \wedge$ & 3 & & & & & 3 \\
\hline $\bar{x} \infty$ & 1 & 2 & & & & 3 \\
\hline$\ddot{x} \sigma$ & 2 & 1 & 1 & 1 & & 5 \\
\hline$\approx 0$ & & 1 & & & & 1 \\
\hline $\overrightarrow{\widetilde{x}}$ & 4 & & & & & 4 \\
\hline$\tilde{x} \sim$ & 1 & 3 & & & & 4 \\
\hline $\boldsymbol{W}$ & 10 & 100 & & $\wedge N$ & $\mathrm{~N}$ & $\infty \infty$ \\
\hline
\end{tabular}

Based on the table above, the writer reported that there are 88 of students' errors with three written corrective feedback of the teacher. There are direct corrective feedback, indirect corrective feedback and metalinguistic corrective feedback.

\section{Direct Corrective Feedback}

Direct corrective feedback is a correction of the teacher which is supported by correct form. Bitchener and Knoch (2009: 411) say "Direct corrective feedback may be defined as the provision of the correct linguistic form or structure by the teacher to the student above or near the linguistic error.

In short, by giving direct corrective feedback, the teacher does not only evaluate students' written text, but also give correct linguistic form. In these students' written text, the teacher used direct corrective by crossing the students' error and replacing with the correct form near the error, and also inserting missing word. 
For example:

$$
\begin{gathered}
\text { likes drinking } \\
\text { It like bone and drink milk. }
\end{gathered}
$$

\section{Indirect Corrective Feedback}

Indirect corrective feedback is a feedback of the teacher to let the students correct their error by themselves. Ellis (2009: 100) says "Indirect corrective feedback involves indicating that the student has made an error without actually correcting it". This can be done by underlining the errors or using cursors to show omissions in the student's text by placing a cross in the margin next to the line containing the error. The writer found that in the students' written text, the teacher had used indirect corrective feedback. The teacher used it by circling and underlining incorrect form, then inserting symbol "?" above it. For example:

$?$

I have my roster,

\section{Metalinguistic Corrective Feedback}

Metalinguistic corrective feedback is a correction of the teacher not only correcting the error but also providing short explanation about the error. Ellis (2009: 100) says "Metalinguistic CF involves providing learners with some form of explicit comment about the nature of the errors they have made". The teacher used metalinguistic corrective feedback by crossing the incorrect form, then giving a note to remember the error. For example: Multimedia one

Error spelling

speker and one fan.

From twenty two students, there are 88 of students' errors which include direct corrective feedback got 42 definitely likes and 33 likes. Indirect corrective feedback got 2 definitely likes, 7 likes 각 2 do not likes. Meanwhile, metalinguistic corrective feedback got 2 likes. The I have my roster, udents' response by using this formula:

$$
\mathrm{N}=\frac{\text { The number of each response }}{\text { Total number of each feedback }} \times 100 \%
$$


| Volume: 1 | Number: 2 | October 2016 | ISSN: 2503 - 4405|

Having counted the percentage of response, the writer presents his calculation on the table below according to the order of the frequency of errors.

Table 3

The Frequency and the Percentage of Responses.

\begin{tabular}{|c|c|c|c|c|c|c|}
\hline \multirow[t]{2}{*}{ No } & \multirow{2}{*}{$\begin{array}{l}\text { Writt } \\
\text { en CF }\end{array}$} & \multicolumn{5}{|c|}{$\begin{array}{c}\text { The Appearance of } \\
\text { Response } \\
\text { Frequency }\end{array}$} \\
\hline & & $\overrightarrow{\mathbf{a}}$ & 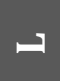 & L & $\bar{z}$ & $\Sigma$ \\
\hline 1 & $\stackrel{0}{\check{0}}$ & $\begin{array}{l}4 \\
2\end{array}$ & $\begin{array}{l}3 \\
3\end{array}$ & - & - & 75 \\
\hline \multicolumn{2}{|c|}{$\mathrm{n} \%$} & $\begin{array}{r}5 \\
6 \\
\% \\
\end{array}$ & $\begin{array}{c}4 \\
4 \\
\% \\
\end{array}$ & - & - & $100 \%$ \\
\hline 2 & 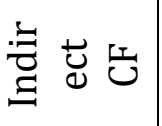 & 2 & 7 & 2 & - & 11 \\
\hline \multicolumn{2}{|c|}{$\mathrm{n} \%$} & $\begin{array}{l}1 \\
8 \\
\%\end{array}$ & $\begin{array}{l}6 \\
4 \\
\% \\
\end{array}$ & $\begin{array}{c}1 \\
8 \\
\% \\
\end{array}$ & - & $100 \%$ \\
\hline 3 & 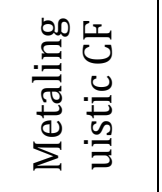 & - & 2 & - & - & 2 \\
\hline \multicolumn{2}{|c|}{$\mathrm{n} \%$} & - & $\begin{array}{c}1 \\
0 \\
0 \\
\%\end{array}$ & - & - & $100 \%$ \\
\hline
\end{tabular}

Based on the table above, it can be seen that there are three written corrective feedback used by the teacher. The first is direct corrective feedback. The teacher used direct corrective feedback on 75 students' errors which include 56\% definitely like and $44 \%$ likes. The second is indirect corrective feedback is on 11 students' errors which include 18\% definitely like, 64\% like and 18\% do not like. The last metalinguistic feedback used by the teacher on 2 students' errors which include $100 \%$ like. This is the result for each written corrective feedback.

Then the writer analyzes the rank of the written corrective feedback by using this formula:

$$
\mathrm{N}=\frac{\text { The number of each response }}{\text { Total number of each of errors }} \times 100 \%
$$


Table 4

The Rank of Written Corrective Feedback

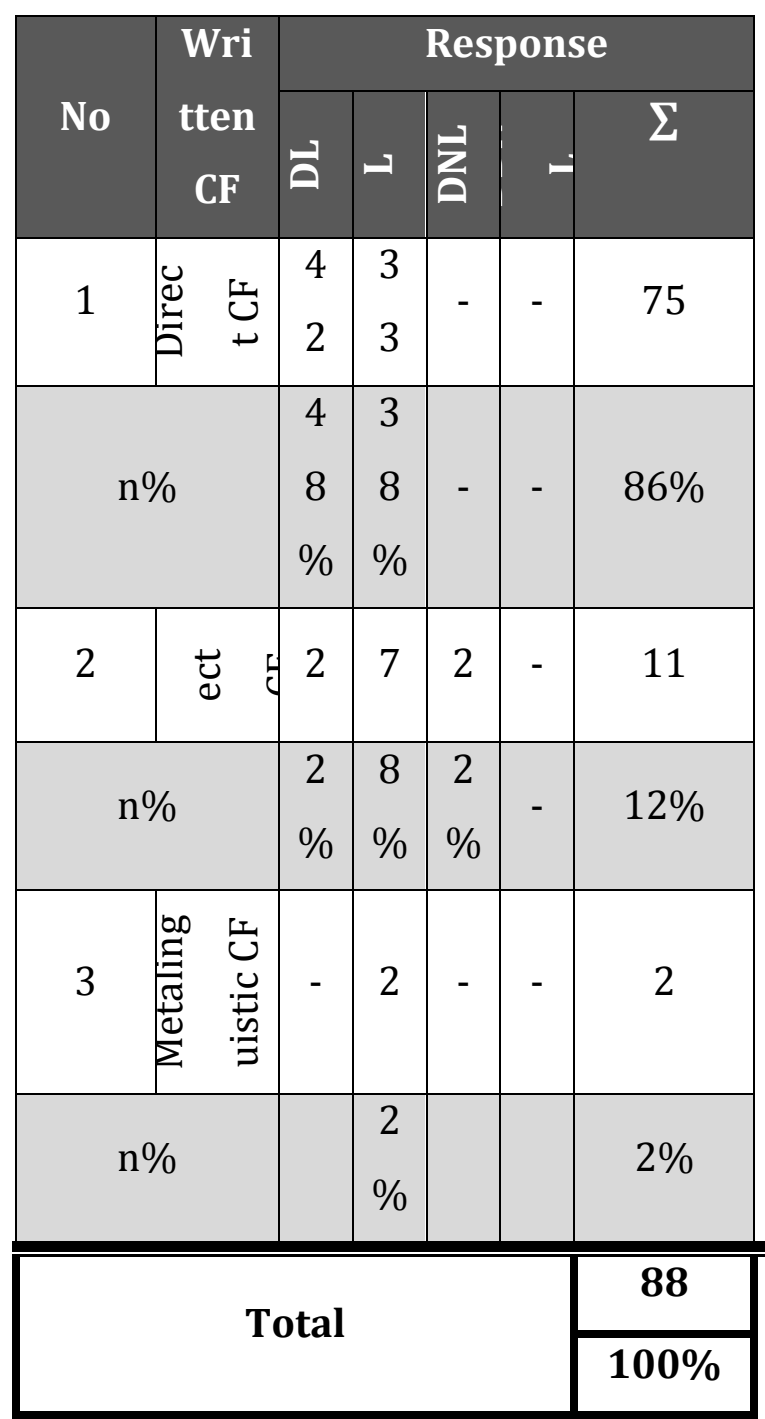

Based on the result of the table above, it can be concluded that the first position is direct corrective feedback with 48\% definitely like and 38\% like. Almost all the students' errors were corrected by direct corrective feedback. Many students gave their good response to this feedback. It can be seen on the questionnaire that they had answered. Their reason why they preferred direct corrective feedback than the others is they could understand their errors without thinking the correct linguistic form because the teacher evaluated the students' errors and also gave the correct linguistic form. So the students only need to reconstruct their written text. Second position is indirect corrective feedback with 2\% definitely like, $8 \%$ like and 2\% do not like. In this feedback, the students did not only give their response for definitely like or like, but also do not like. From questionnaire that they 
| Volume: 1 | Number: 2 | October 2016 | ISSN: 2503 - 4405|

had answered, they did not understand with indirect corrective feedback. The teacher only gave symbol "?" on the students' errors. So that is why the students felt confused with this feedback. The last position is metalinguistic corrective feedback with $2 \%$ like. This is the written corrective feedback of teacher which the most little feedback used to correct the students' errors by the teacher. Only 2 students' errors were corrected by metalinguistic corrective feedback and got $2 \%$ like of the students' response. From the students who got this feedback, they stated that they understand with metalingustic corrective feedback.

From the research finding above, it is supported with the result of an interview. At second day, the writer conducted an interview with the English teacher and four students who got the highest until the lowest score on their written text. From the interview with the teacher, the writer found that the result of analyzing written corrective feedback of the teacher is equivalent with what the English teacher stated in interview.

The teacher used direct corrective feedback, indirect corrective feedback and metalinguistic corrective feedback to evaluate students' written text. From three types of written corrective feedback, she stated that almost all the students liked and understood direct corrective feedback. In direct corrective feedback, she crossed out, underlined, or circled the students' errors and gave the correct answer. The teacher used indirect corrective feedback to evaluate the students' error. She did not only give the correct form or explanation but also give symbol "?" for the students. The students were let think their errors and how to correct them by themselves. The teacher wanted to make her students become independent students. The teacher also stated that she used metalinguistic corrective feedback. She did not only cross out, underline, circle the students' errors or give code, but also give short explanation about the errors. It was aimed for the students to remember their errors and do not make the same errors next time.

Meanwhile, the writer also did an interview with four students. The first student stated that he understood all the written corrective feedback, but he preferred direct corrective feedback and metaliguistic feedback. He also explained the reason why he preferred those written corrective feedbacks. He really understood about his errors because the teacher gave the correct form and also short explanation about the errors. So he did not only know the correct form but he also could reconstruct his errors become good written text. The second student explained that he understood the teacher's written corrective feedback, but he preferred direct corrective feedback more than the others. He said that with direct corrective feedback, he only needed to change his errors and replace 
| Volume: 1 | Number: 2 | October 2016 | ISSN: 2503 - 4405|

them with the correct forms from the teacher. This was also stated by the third and fourth students. The students preferred direct corrective feedback too. They stated that their errors were easy to understand if they were corrected by direct corrective feedback. The writer found that the data which had been analyzed from questionnaire and interview are equivalent.

\section{B. Conclusion}

This study aims to find what written corrective feedbacks which used by the tenth grade teacher and describe the students' response to the teacher's written corrective feedbacks. Based on the research findings, the writer proposes some conclusions as follows:

1. The teacher uses direct corrective feedback, indirect corrective feedback and metalinguistic corrective feedback to correct the students' written work of descriptive text. Firstly, she uses direct corrective feedback by inserting missing words, and crossing out, circling or underlining the students' errors then replacing with the correct linguistic forms. Secondly, the teacher uses indirect corrective feedback by giving a mark "?" near the errors of the students. The last is metalinguistic corrective feedback. The teacher uses it by crossing the incorrect form, then giving a note to remember the errors.

2. Most students who get teacher's direct corrective feedback have better understanding about the errors in their written text especially in simple present tense. It can be seen that from 88 students' errors, direct corrective feedback gets $48 \%$ definitely like and 38\% like, indirect corrective feedback gets 2\% definitely like, $8 \%$ like and $2 \%$ do not like and metalinguistic corrective feedback gets $2 \%$ like.

\section{BIBLIOGRAPHY}

Ary, D., Jacobs, L. C., Sorensen, C. K., \& Razavieh, A. (2010). Introduction to Research in Education $8^{\text {th }}$ Edition. Belmont, CA: Wadsworth, Cengage Learning.

Bitchener, J. \& Knoch, U. 2008. The Value of Written Corrective Feedback for Migrant and International Students. Language Teaching Research, 12(3): 409-431.

Brown, H. Douglas. 2000. Teaching by Principles: An Interactive Approach to Language Pedagogy. New York: Longman. 
| Volume: 1 | Number: 2 | October 2016 | ISSN: 2503 - 4405|

Cochran, M., \& Patton, M. Q. 2002. A Guide to Using Qualitative Research Methodology. London: Medecins Sans Frontieres.

Dornyei, Z. 2007. Research Methods in Applied Linguistics: Quantitative, Qualitative, and Mixed Methodologies. New York: Oxford University Press.

Ellis, R. 2009. A Typology of Written Corrective Feedback Types. ELT journal, 63(2): 97-107.

Johns, A. M. (Ed.). 2002. Genre in the Classroom: Multiple Perspectives. London: Lawrence Erlbaum Associates.

Karimi, S. H. (2016). Effects of Different Types of Teacher Written Corrective Feedback on Iranian EFL Learners' Writing Accuracy. Journal of Applied Linguistics and Language Research, 3(2): 216-229.

Knapp, P. \& Watkins, M. 2005. Genre, Text, Grammar: Technologies for Teaching and Assessing Writing. Sydney: UNSW Press.

Larsen-Freeman, D. \& Anderson, M. 2013. Techniques and Principles in Language Teaching $3^{\text {rd }}$ Edition. New York: Oxford University Press.

Mahmoodi, F. \& Rajabi, S. 2015. The Effect of Oral and Written Feedback on Writing Performance and Self-Regulation of EFL Learners. Indian Journal of Fundamental and Applied Life Sciences, 5(2): 1870-1878

Marczyk, G., DeMatteo, D., \& Festinger, D. 2005. Essentials of Research Design and Methodology. Canada: John Wiley \& Sons Inc.

Russell, J., \& Spada, N. 2006. The Effectiveness of Corrective Feedback for the Acquisition of L2 Grammar. Synthesizing Research on Language Learning and Teaching, 133-164. 